British Journal of Marketing Studies (BJMS)

Vol. 8, Issue 2, pp.1-25, March 2020

Published by ECRTD- UK

Print ISSN: 2053-4043(Print), Online ISSN: 2053-4051(Online)

\title{
CUSTOMER SELF SERVICE TECHNOLOGY AND CUSTOMER PATRONAGE OF DEPOSIT MONEY BANKS IN RIVERS STATE
}

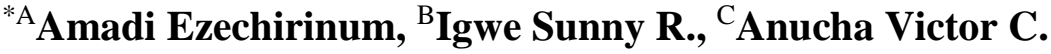 \\ ${ }^{\mathrm{a}, \mathrm{c}}$ Department Of Marketing, Ignatius Ajuru University of Education- Nigeria \\ ${ }^{b}$ Department Of Marketing, University of Port Harcourt, Choba-Nigeria \\ *Corresponding Author: Ezechirinum Amadi, ezvidik@yahoo.com \\ P.O.Box 488 Uniport Post Office, Port Harcourt - Nigeria
}

\begin{abstract}
This study investigates the relationship between Customer Self Service Technology and Customer Patronage of Deposit Money Banks in Rivers State. The objectives of the study were to investigate the influence of Customer Self Service Technology on Customer Patronage. The study adopted the survey research design. The choice of this survey approach is because it will scientifically look at the situation on ground and will empirically analyze it to get result that can be attributable to the accessible population. Based on the research questions, a research questionnaire was designed and four hundred and seventy five (475) copies were distributed to the sample population which was determined by convenient sampling techniques. After data cleaning, a total of three hundred \& twenty one (321) copies of the distributed questionnaire were retrieved. These copies were analyzed and the hypotheses were tested using the Spearman Rank Correlation Coefficient with the aid of SPSS Version 21.0. The result revealed that there is a significant relationship between Automated Teller Machine and repeat purchase, Automated Teller Machine and referral, Internet banking and repeat purchase, Internet banking and referral. The result also revealed that customer technology adoption positively influences the relationship between customer self-service technology and customer patronage in deposit money banks in Rivers State. The study concluded that consumer orientation should be applied whenever banks are adopting new techniques that will service the need of their customers for better satisfaction. The study recommends that Banks should invest more on technologies that will ensure efficiency in serving customer and overall satisfactions of the customers. Customer satisfaction should be kept in mind as banks upgrade existing systems or while buying new systems altogether.
\end{abstract}

KEYWORDS: customer self-service technology, customer patronage, customer satisfaction, internet banking.

\section{INTRODUCTION}

In the era of globalization, expectations for companies and banks to be able to continue growing can be concentrated on creating loyal customers. This makes companies and banks try to create a competitive advantage through innovative efforts and creativity to retain loyal customers. Oliver (1996) defined customer loyalty as the commitment of the customers to repurchase a product or service consistently in the future, although there are situations which potentially cause change in behavior such as influences of other people or marketing efforts conducted by competitors. Guiltinan et al. (1997) also found that satisfied customers were more likely to repeat the purchase 
of products or services and even become loyal customers and not to think of switching to another banks.

Today's fast-paced world is becoming increasingly characterized by technology-facilitated transactions. Growing numbers of customers interact with technology to create service Outcomes instead of interacting with a service firm employee. Self-service technologies (SSTs) are technological interfaces that enable customers to produce a service independent of direct service employee involvement. Examples of SSTs include automated teller machines (ATMs), automated hotel checkout, banking by telephone, and services over the Internet, such as Federal Express package tracking and online brokerage services.

Currently, handling day to day banking operations cannot be separated from the use of computer technology in order to achieve effectiveness and efficiency, especially in meeting the demands of customers. The application of technology such as self-service technology (SST) in on-line banking system, internet banking, mobile banking, mobile phone-based (phone banking), the use of Automatic Teller Machine (ATM) is one of bank's strategies in retaining and satisfying customers and in creating a competitive advantage in an effort to compete with other banks. According to Bobbitt and Dabholkar (2001) rapid use of technology in self-service technology indicates that consumers have changed how they access various services, including accessing banking services. This is evident from the growing number of products or services using technology and the growth of the role of technology in a manufacturer-customer interaction which has been very rapid since the beginning of the 21st century (Parasuraman, 2000; Howard \& Worboys, 2003). As customer service is an essential factor in the current market place, retailers are adopting self-service technologies (SSTs) to improve the quality of service. Technological interfaces enable companies to delight their customers instantly by allowing them to solve their problems using technology (Bitner et al., 2002).

Banks that deliver successful self-service solutions undoubtedly carve a niche for their selves and have a different orientation. They create an experience that customers genuinely want, find valuable and are excited about. They then deliver that experience in a way that customers control. This mindset shift from "self-service" to "digital do-it-yourself" can make a huge difference in customers' adoption rates. Importantly, the most successful banking self-service strategies encourage customers to opt in; they do not simply foist self-service upon their customers, with the expectation that they will comply. In other words, self-service should not be something banks do to their customers. It should be a channel they develop with their customers. This means designing self-service solutions that are simple to use, address the needs of customers (not banks), and allow customers to control their experience. 
British Journal of Marketing Studies (BJMS)

Vol. 8, Issue 2, pp.1-25, March 2020

Published by ECRTD- UK

Print ISSN: 2053-4043(Print), Online ISSN: 2053-4051(Online)

From empirical point of view, many studies have been carried out on the construct and concept of self service technology banking with other construct and practices. For instance; Cunningham, Young, and Gerlach, (2008) studied "Consumer Views of Self-Service Technologies". Meuter, Ostrom, Roundtree, and Bitner, (2000) examined Self-Service Technologies: Understanding Customer Satisfaction with Technology-Based Service Encounters. Ombati, Magutu, Nyamwange, and Nyaoga, (2010), investigated on "Technology and service quality in the banking industry". Joshua, (2009), worked on "Adoption of Technology Enabled Banking Self Services antecedents and consequences". It is therefore factual that from the listed empirical studies, most studies have not critically looked at how self-service technology has improved the loyalty of customers towards such practices. A literature gap therefore exist and our departure point is to empirically investigate the relationship between customer self-service technology and customer patronage of deposit money banks in Rivers State.

\section{Statement of the Problem}

With the increasingly intense levels of competition among banks, there is intense race to provide high level of satisfaction to customers. Giving satisfaction to customers is very important and is the key in creating customer loyalty because banks will get a lot of benefit from the achievement of a high level of satisfaction. In addition to preventing customers switching to other banks, a high level of satisfaction may also be provided in order to reduce customer sensitivity to price, which may reduce service costs and, in turn, improve the reputation of marketing failures (Fornell, 1992). This can create high customer loyalty that will create the worth of mouth regarding the banks ${ }^{\text {ee }}$ good reputation. Getting satisfaction as expected, customers will express high level satisfaction which can be the step of managing customers to create realistic expectations (Jones et al., 2007).

Presently, the level of awareness is very poor with the introduction of technological innovation in the banking systems in terms of self service which perhaps may have helped in reducing the waiting line in the bank. Most customers are yet to adopt the innovation as many experience users still complain of bad network service, privacy and security issue as well as lack of customer service support. The satisfaction derived from a service could stimulate the continuous loyalty of a customer to such product or services. Many studies are yet to focus their attention on how this concept of self service technology can enhance customer loyalty and improve performance. This study therefore seeks to evaluate the use of self service technology on customer patronage in the banking sector in Rivers State. 


\section{Conceptual Framework}

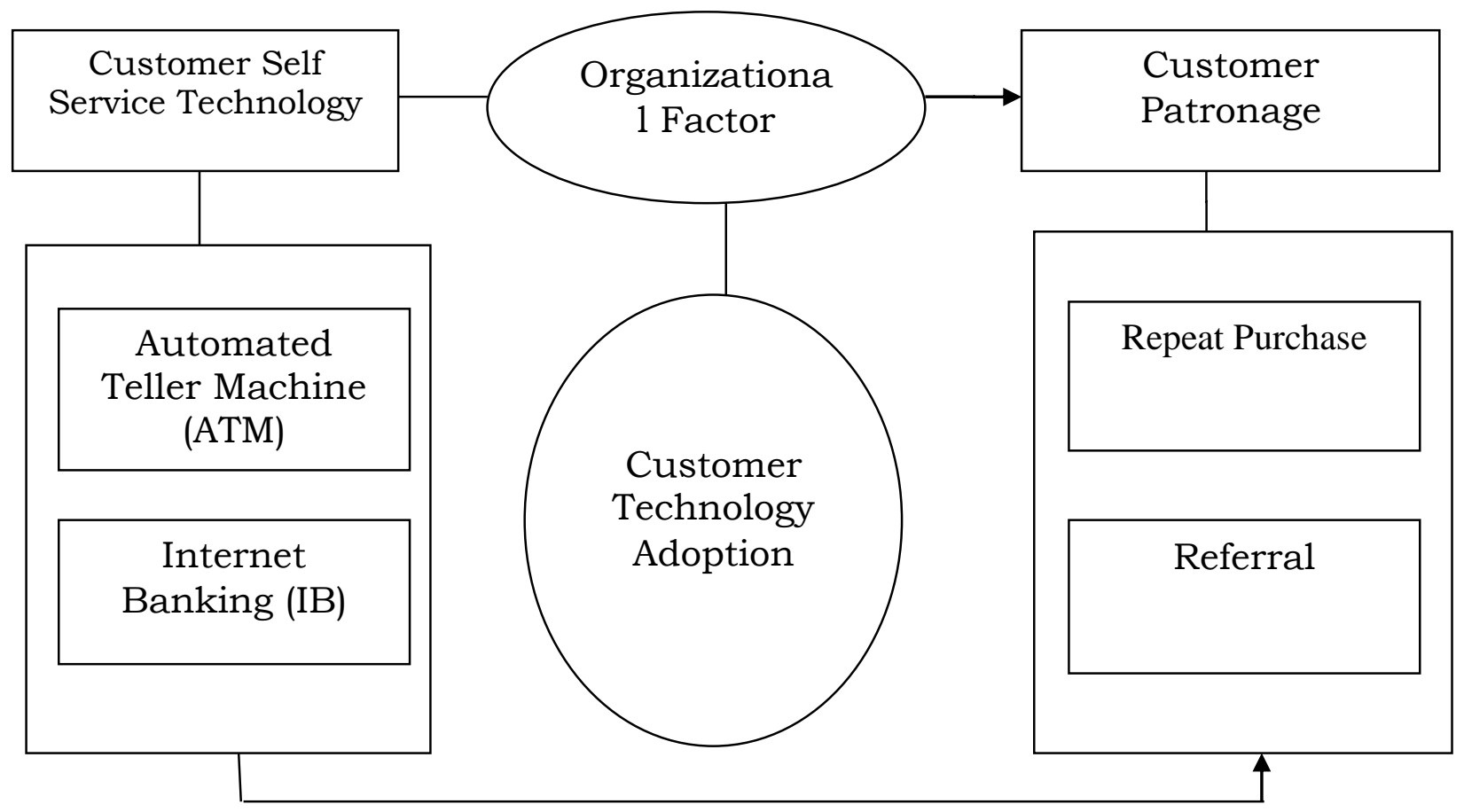

Figure 1: Conceptual Framework on the Relationship between Customer Self Service Technology and Customer Patronage in Deposit Money Banks in Rivers State

Source: Researcher's Conceptualization from Review of Related Literature, 2019

\section{Objectives of the Study}

The general objective of this study was to examine the relationship between the customer self service technology and customer patronage in deposit money banks in Rivers State. Concisely, the following specific objectives include:

i. To examine the relationship between automated teller machine and customer patronage of deposit money banks in Rivers State.

ii. To examine the relationship between internet banking and customer patronage of deposit money banks in Rivers State.

iii. To determine the extent to which consumer technology adoption influence the relationship between customer self service technology and customer patronage of deposit money banks in Rivers State. 
British Journal of Marketing Studies (BJMS)

Vol. 8, Issue 2, pp.1-25, March 2020

Published by ECRTD- $U K$

Print ISSN: 2053-4043(Print), Online ISSN: 2053-4051(Online)

\section{Research Questions}

In this section of the study, the following research questions were stated;

i. To what extent does automated teller machine influence customer patronage of deposit money banks in Rivers State?

ii. To what extent does internet banking influence customer patronage of deposit money banks in Rivers State?

iii. To what extent does customer technology adoption influence the relationship between customer self-service technology and customer patronage of deposit money banks in Rivers State?

\section{Research Hypotheses}

The following null hypotheses are formulated to guide the study:

Ho1: There is no significant relationship between automated teller machine and repeat purchase in deposit money banks in Rivers State.

Ho2: There is no significant relationship between automated teller machine and referral in deposit money banks in Rivers State.

Ho3: There is no significant relationship between internet banking and repeat purchase in deposit money banks in Rivers State.

Ho4: There is no significant relationship between internet banking and referral in deposit money banks in Rivers State

Hos: Customer technology adoption does not significantly influence the relationship between customer self service technology and customer patronage in deposit money banks in Rivers State.

\section{LITERATURE / THEORETICAL UNDERPINNING}

\section{Theoretical Review}

Technology Acceptance Model has been developed by Davies (1989) is one of the most popular research models to predict use and acceptance of information systems and technology by individual users.

TAM has been widely studied and verified by different studies that examine the individual technology acceptance behavior in different information systems constructs. In TAM model, there 
are two factors perceived usefulness and perceived ease of use is relevant in computer use behaviors. Davies (1989) defines perceived usefulness as the prospective user's subjective probability that using a specific application system will enhance his or her job or life performance. Perceive ease of use (EOU) can be defined as the degree to which the prospective user expects the target system to be free of effort. According to TAM, ease of use and perceived usefulness are the most important determinants of actual system use. These two factors are influenced by external variables. The main external factors that are usually manifested are social factors, cultural factors and political factors. Social factors include language, skills and facilitating conditions. Political factors are mainly the impact of using technology in politics and political crisis. The attitude to use is concerned with the user's evaluation of the desirability of employing a particular information system application. Behavioral intention is the measure of the likelihood of a person employing the application.

\section{Conceptual Framework}

\section{a. Customer Self-Service Technology}

Self-service technology is defined as a technological interface that aid users generating service without direct involvement from the service company employee (Meuter et al., 2000). Self-service facilities are where consumers deliver services themselves through the use of technology (Meuter et al, 2000). Self-service technology cuts across a range of services, from traditional high contact services such as hotels to low contact services such as filling the car with petrol (Curran, Meuter $\&$ Suprenant, 2003; Meuter et al., 2000).

The purpose of SST usage can be classified as customer service, transactions and self-help (Meuter et al., 2000). SST channels in the banking industry include; Internet banking (IB), Mobile banking, automated teller machine (ATM) and electronic fund transfer (EFT).

These technologies allow customers to withdraw funds, transfer funds anytime, anywhere they want and accessibility has been extended through technological development as it allows customers to do business from their home and office. It makes the banking activities and transaction simpler to understand while reducing the waiting time of the customer; no long queue standing is required. SST ensures there is no requirement of direct control with bank, as services can be operating wherever customer wants 24 hours a day, seven days a week.SST has enabled the corporate and retail customers to transact from home, office and traveling and significantly improved communication, and interaction between the bank and customer has been improved.

Past studies have acknowledged that personal interactions between consumers and front-line employees are important for consumer satisfaction and consumer commitment (Ganesh, Arnold and Reynolds, 2000). And now with rapid adoption of SST, the concern is the impact this potential 
British Journal of Marketing Studies (BJMS)

Vol. 8, Issue 2, pp.1-25, March 2020

Published by ECRTD- UK

Print ISSN: 2053-4043(Print), Online ISSN: 2053-4051(Online)

loss of personal interaction may have on these evaluations, as consumer satisfy action and consumer commitment that are important for organizational survival (Anderson, Fornell \& Lehmann, 1994).

The ability to obtain self-service customers and manage customer production challenges much of the existing knowledge. Brown (2000) states that "it now seems that most of what we know about services marketing and management has been derived from the study of face-to-face service encounters or at least over the telephone". Cumby and Barnes (1996) suggested that the affective dimensions of an exchange have an overriding influence on all other elements during service provision. The assertion here is that consideration of the feelings produced by how the customer is treated by or interacts with employees of the service organization is critical to the effective management of the service encounter (Cumby and Barnes, 1996). Zeithaml et al. (1990) even suggested that replacing contact employees with technology may hurt a service firm's performance since employees can better develop relationships with customers. In short, when companies consider developing TBSS, the impact of replacing interpersonal contact between the customer and the service provider cannot be underestimated. The study therefore adopted automated teller machine (ATM) and internet banking as the dimensions of customer self service technology.

\section{b. Customer Patronage}

According to the New Webster Dictionary (1994), Patronage can be said to mean "the material help and encouragement given by a patron, in this instance the patron in seen to be a customer in an exchange transaction. It could also mean "the act of being a regular customer to a shop. In a highly competitive industry, such as banking, satisfying the customers should be the primary focus of firms that wish to sustain patronage (Johns \& Tyas, 1996; Kivela, Inbakaran, \& Reece, 1999; Sulek \& Hensley, 2004).

Service organizations can enhance customers purchase behavior by creating value in product offerings to meet customers' expectations and satisfy their needs. Fishbein and Ajzen (1975) view consumerse purchase intention as an important indicator for predicting consumer behavior. Patronage intention describes the likelihood that the consumer will be willing to buy a specific product in the future. Zeithaml (1988) notes that merchandize value perceptions drive purchase intentions and purchase behavior in organizations. Literature on regulatory focus theory abound (Wirtz \& Lwin, 2009;Brockner, Higgins, \& Low, 2004; Dodds et al, 1991; Lee, Aaker, \& Gardner, 2004; Lockwood, Jordan \& Kunda, 2002; Friedman \& Forster, 2001).

Consumer research has examined the influence of merchandise value perceptions on consumer behavior (e.g., Dodds et al, 1991; Zeithaml et al, 1990) and shown that consumers' evaluations of merchandise or product value impact their patronage intentions in traditional stores. Therefore, purchase intention is found to be influenced by product value. Consumers' intention to purchase 
British Journal of Marketing Studies (BJMS)

Vol. 8, Issue 2, pp.1-25, March 2020

Published by ECRTD- UK

Print ISSN: 2053-4043(Print), Online ISSN: 2053-4051(Online)

can also be seen as a connection between their attitude towards a product and its actual purchase. According to Fishbein and Ajzen (1975), there are three notable measurement items for gauging purchase intentions: possible to buy, intended to buy and consider buying. For the purpose of this study, we hereby adopt the variables of repeat purchase and referral as the measures of customer patronage.

\section{c. Customer Self Service Technology and Customer Patronage}

In a self-service system, the degree of a consumer's direct and active involvement in the service process is higher than that in other service systems. For example, Wikström refers to self-service as "a sort of joint venture in the marketplace, in which the consumer increasingly assumes the role of co-producer". The success of a bank in maintaining its customers to remain loyal to the bank depends on the implementation of marketing strategies such as product innovation, the provision of self-service technology that prioritizes user-friendly and fast service provision which can be done through electronic banking (e-banking), promotion, and improvement of service quality (Kurniasih, 2012). In addition, some banks from year to year always increase the number of ATMs and self-service facilities, and other technology to support electronic banking services aimed at satisfying customers. Ganguli and Roy (2011) in their research showed that four dimensions of quality service generic in technology-based banking services, including customer service, security technology and quality information, simplicity technology, and technology simplicity use and reliability. These four dimensions would positively influence customer satisfaction and customer loyalty. This is supported by the study of Buell et al. (2010) which stated that the use of self-service technology (SST) would influence customer satisfaction and retention as well as the switching cost. Proenca and Rodrigues (2011) also found that the users of self-service technology (such as ATMs, telephone banking, and internet banking) were more satisfied with the service provided by their banks compared to non-users of self-service technology. In addition, users of self-service technology of banks were more likely to express positive word of mouth than non-users of selfservice technology.

According to Bobbitt and Dabholkar (2001) rapid use of technology in self-service technology indicates that consumers have changed how they access various services, including accessing banking services. This is evident from the growing number of products or services using technology and the growth of the role of technology in a manufacturer-customer interaction which has been very rapid since the beginning of the 21st century (Parasuraman, 2000; Howard \& Worboys, 2003). In addition, Devlin (1995) stated that the banking industry is one of the pioneers in the adoption of automation services as providers recognized as technology innovation in banking services which provide opportunities to differentiate themselves from competitors. Specifically, banks with enthusiastic adopted self-service technology of various types, including automatic teller machines (ATMs), telephone banking, internet banking, and mobile banking or 
British Journal of Marketing Studies (BJMS)

Vol. 8, Issue 2, pp.1-25, March 2020

Published by ECRTD- $U K$

Print ISSN: 2053-4043(Print), Online ISSN: 2053-4051(Online)

SMS banking, all of which could be utilized by customers independently to meet their needs without having to interact with bank employees (Meuter et al., 2000).

In the context of self-service interactions between the consumer and service provider, the human element is eliminated from the service provider's side. Consequently, the interaction type 'humanhuman' is not part of the self-service concept. The 'high-touch' that usually characterizes services is replaced with 'high-tech'. In the current literature, technology is considered an enabler of selfservice offerings.

\section{* Automated Teller Machine (ATM) and Customer Patronage}

The ATM is an innovative service delivery mode that offers diversified financial services like cash withdrawal, funds transfer, cash deposits, payment of utility and credit card bills, cheque book requests and other financial enquiries (Khan, 2010). Rose (1999) described ATM as follows: an ATM combines a computer terminal, record keeping system and cash vault in one unit, permitting customers to enter the bank's record keeping system with a plastic card containing a Personal Identification Number (PIN) or by punching a specific code into the computer terminal linked to the bank's computerized records 24-hours a day. A customer can access an ATM machine by using an ATM card. An ATM card is a plastic card that allows the bank account holder to do the same things at an ATM as he or she would do at a bank (Woelfel, 1994). Islam et al. (2007) also referred to ATM as a type of innovation that can mechanically accept deposits, issue withdrawals, transfer funds between accounts, collect bills and make small loans. A well-functioning ATM is a sure way of improving service quality in the banking industry.

Nigeria has witnessed rapid growth in the introduction and diffusion of Information and Communication Technologies (ICT) in its banking sector. Agboola (2006) found that the use of ICT in Nigerian banks has produced largely positive outcomes such as improved customer services, more accurate records, ensuring convenience in business time, prompt and fair attention and faster services. Work has been made easier, and more interesting, the competitive edge of banks, relationship with customers, and the solution of basic operational and planning problems has been improved (Olatokun \& Igbinedion, 2009). However, among the more modern banking services such as electronic banking, internet banking, point of sales (POS) transactions, money transfer, ATMs emerged as the most popular. ATM awareness also ranked higher than awareness level about current accounts and slightly below savings. The following hypotheses are hereby stated; 
British Journal of Marketing Studies (BJMS)

Vol. 8, Issue 2, pp.1-25, March 2020

Published by ECRTD- UK

Print ISSN: 2053-4043(Print), Online ISSN: 2053-4051(Online)

Ho1: There is no significant relationship between automated teller machine and repeat purchase

Ho2: There is no significant relationship between automated teller machine and referral

\section{* Internet Banking and Customer Patronage of Deposit Money Banks}

Internet banking refers to the use of the Internet as a remote delivery channel for banking services. Such services include traditional ones, such as opening a deposit account or transferring funds among different accounts, and new banking services, such as electronic bill presentment and payment (allowing customers to receive and pay bills on a bank's Web site). Banks offer Internet banking in two main ways. An existing bank with physical offices can establish a Web site and offer Internet banking to its customers as an addition to its traditional delivery channels. A second alternative is to establish a "virtual," "branchless," or "Internet-only" bank. The computer server that lies at the heart of a virtual bank may be housed in an office that serves as the legal address of such a bank, or at some other location.

Internet Banking is defined as the usage of Internet and telecommunication networks to deliver banking services to customers. Customers can inquire information and carry out most banking services such as account balance inquiry, inter-account transfers, and bill-payment via the Internet. There are different perceptions of Internet Banking between the literature and practitioners. Internet banking is a web application based on client/server architecture in which Internet technology plays an important role.

Internet Banking allows account aggregation. With account aggregation, customers can manage several banking accounts held at different banks via a unique access point. This means that customers just log on to the Internet Banking websites which support account aggregation enable customers to access their account held at other banks, including deposit account, credit cards and award programs (Li, 2001). To use account aggregation service, a customer has to give settings such as the URL, user name and password of each external account. Once customer logs on to an account aggregation website, this system automatically logs onto other banks' Internet Banking sites just as if a customer is logged on to them directly. With account aggregation, a customer is able to access all information from an account held at another bank. This provides customers with convenience and time saving. Although this has many advantages to the customers, security, level of information access and legal standards to protect the banks and customers has led to a slow adoption. In view of the above, we therefore state the following hypotheses:

Ho3: There is no significant relationship between internet banking and repeat purchase

Ho4: There is no significant relationship between internet banking and referral 


\section{Moderating influence of Customer Technology Adoption on the Relationship between Customer self Service Technology and Customer Loyalty}

Acceptance is adoption and continuing use of the product, service or idea. According to Rogers and Shoemaker (1971), consumers go through "a process of knowledge, persuasion, decision and confirmation" before they are ready to accept a product or service. Individuals who are skilled and always using the internet significantly affect the acceptance of Internet banking services. Users who are experienced in using computers and the Internet will influence them to use Internet banking services (Lassar et. al, 2005). The acceptances of internet banking services can be investigated through identifying the reasons of the use of internet banking (Eriksson et. al, 2005).

Shih and Fang (2003)agreed that the factors of behavior intention to use the Internet banking, which is the actual usage of banking transaction, attitude, subjective norms, perceived and relative advantages of the Internet banking, and normative influences. They also agreed with WungwanitChakorn (2000) that compatibility and complexity of the Internet banking will influence the acceptance of the Internet banking usage. E-banking is regarded as an important delivery channel that offered one-stop services and information unit to gain competitive advantages in banking sector (Malek AL-Majadi and NikKamariahNik Mat, 2011). These studies contend that the currently relevant factors determining the adoption of Internet banking in Nigeria include the level of awareness or attention, the accessibility to computers and the Internet, convenience, privacy, costs, and the availability of knowledge and support concerning internet banking. On the other hand, Al-Somali et al. (2008) noted that low awareness of Internet banking is a critical factor in causing customers not to adopt internet banking and concurs that most important factors discouraging the use of Internet banking are lack of Internet access and not having a chance to try out Internet banking in a safe environment, thus not being in a position to access account.

According to Ganesh et al. (2000), the previous studies have identified that user input factors are a function of control, enjoyment and intention to use. Control could be described as the amount of effort and involvement required by consumers in electronic banking. On this basis, we state the following hypothesis:

Hos: Customer technology adoption does not significantly influence the relationship between customer self-service technology and customer patronage in deposit money banks in Rivers State.

\section{METHODOLOGY}

Our study adopted quasi-experimental research design which employed cross sectional survey approach. Sullivan (2001) asserts that a survey "is a data collection technique in which information is gathered from individuals by having them respond to questions or statements". Survey method is also useful because it supports our triangulations of methodology as Sullivan (2001) believes 
British Journal of Marketing Studies (BJMS)

Vol. 8, Issue 2, pp.1-25, March 2020

Published by ECRTD- UK

Print ISSN: 2053-4043(Print), Online ISSN: 2053-4051(Online)

that some survey methods allow for the use of both questionnaire and other data collection techniques like informal discussion, documented evidence. Besides, the quasi-experimental research design was adopted due to the complex relationship that exists between the study variables. This choice is informed by the fact that the researcher does not have perfect control of the variables that could affect the study. Therefore a non-contrived research setting was adopted. Our population consisted of all money deposit bank customers in the 19 deposit money banks in Rivers State. The researcher purposively administers twenty (25) copies of questionnaire to customers in each of the nineteen (19) deposit money banks in Rivers State. This gave a total of four hundred and seventy five (475) copies.

Table 1: List of Quoted Banks in Rivers State

\begin{tabular}{|l|l|l|}
\hline S/No. & Names of Quoted Banks in Rivers State & $\begin{array}{l}\text { Number to be given each } \\
\text { bank customers }\end{array}$ \\
\hline 1 & Unity Bank Plc & 25 \\
\hline 2 & Citibank Nigeria & 25 \\
\hline 3 & Wema Bank Plc & 25 \\
\hline 4 & Zenith Bank Plc & 25 \\
\hline 5 & Heritage Bank & 25 \\
\hline 6 & Keystone Bank & 25 \\
\hline 7 & Union Bank & 25 \\
\hline 8 & Standard chartered bank & 25 \\
\hline 9 & Access/Diamond Bank Plc & 25 \\
\hline 10 & Ecobank Plc & 25 \\
\hline 11 & Suntrust Bank Plc & 25 \\
\hline 12 & First City Monument Bank (FCMB) & 25 \\
\hline 13 & Fidelity Bank Plc & 25 \\
\hline 14 & First Bank Plc & 25 \\
\hline 15 & Guarantee Trust Bank Plc & 25 \\
\hline 16 & Polaris Bank Plc & 25 \\
\hline 17 & Stanbic Bank & 25 \\
\hline 18 & Sterling Bank & 25 \\
\hline 19 & United Bank of Africa (UBA) & $\mathbf{4 7 5}$ \\
\hline & TOTAL & \\
\hline
\end{tabular}

Source: Nigerian Stock Exchange; March, 2019 
British Journal of Marketing Studies (BJMS)

Vol. 8, Issue 2, pp.1-25, March 2020

Published by ECRTD- UK

Print ISSN: 2053-4043(Print), Online ISSN: 2053-4051(Online)

The instruments used for data collection involved the questionnaire and documentary instrument. For the purpose of this study, a self-administered, questionnaire was employed. The questionnaire was structured into sections A and B. Section A dealt with the demographics of the respondents, while section $B$ dealt with the study variables. The questions were designed in a simple format to ease administration. Multiple choice methods were adopted in framing the questions and the questions were structured using five-point Likert scale which solicited information from the customers of the bank chosen for the study.

In this study, we adopted a combination of descriptive and inferential statistical tools with statistical package for social sciences (SPSS) version 21.0 facilitating the analysis. Charts, frequency tables, means, as well as percentages constituted the descriptive statistical tools used to conduct the necessary demographic and univariate analysis. Bivariate and multivariate analyses will be carried out through parametric inferential statistical tools. The Spearman's Rank (rho) correlation will be used to analyze the relationship between independent and dependent variables at $\mathrm{P}>0.01$ (two-tailed test).

\section{RESULTS AND FINDINGS}

\section{Analysis of Responses}

\section{Table 2: Automated Teller Machine (ATM)}

\begin{tabular}{|c|c|c|c|c|c|c|c|c|}
\hline $\mathbf{S} / \mathbf{N}$ & Opinions & SA & $\mathbf{A}$ & $\mathbf{U}$ & $\mathbf{D}$ & SD & Mean & Total \\
\hline & & No $\%$ & No $\%$ & No $\%$ & No $\%$ & No $\%$ & & No $\%$ \\
\hline 1 & I find using the ATM very simple & $116(36)$ & 76 (24) & $59 \quad(18)$ & 33 (10) & $37 \quad(12)$ & 3.63 & $321 \quad 100$ \\
\hline 2 & $\begin{array}{l}\text { I prefer using ATM for my utility } \\
\text { payments }\end{array}$ & $98 \quad(31)$ & $114(36)$ & $\begin{array}{ll}62 & (19)\end{array}$ & $27 \quad(8)$ & $20 \quad(6)$ & 3.76 & $321 \quad 100$ \\
\hline 3 & $\begin{array}{l}\text { I require nobody to interpreted the } \\
\text { ATM command for me }\end{array}$ & $105(33)$ & 78 (24) & $69 \quad(22)$ & 42 (13) & $27 \quad(8)$ & 3.59 & $321 \quad 100$ \\
\hline 4 & $\begin{array}{l}\text { I use another banks ATM with my } \\
\text { bank ATMcard easily }\end{array}$ & $76(24)$ & $116(36)$ & $59 \quad(18)$ & $33 \quad(10)$ & $\begin{array}{ll}37 & (12)\end{array}$ & 3.63 & $321 \quad 100$ \\
\hline 5 & $\begin{array}{l}\text { I access many ATM point at a very } \\
\text { close distance }\end{array}$ & $98 \quad(31)$ & $114(36)$ & $62 \quad(19)$ & $27 \quad(8)$ & $20 \quad(6)$ & 3.76 & $321 \quad 100$ \\
\hline
\end{tabular}

Source: Survey Data, 2019

Table 2 shows respondents' views on automated teller machine (ATM) with the mean value of $\bar{x}=3.63$. On the first question on the table, $36 \%$ of the total respondents indicated strongly agree, $24 \%$ indicated agree, $18 \%$ indicated undecided, $10 \%$ of respondents indicated disagree. While, 
British Journal of Marketing Studies (BJMS)

Vol. 8, Issue 2, pp.1-25, March 2020

Published by ECRTD- UK

Print ISSN: 2053-4043(Print), Online ISSN: 2053-4051(Online)

$12 \%$ of respondents indicated strongly disagree. To the second option, a mean value of $\bar{x}=3.76$ was obtained $31 \%$ of respondents indicated strongly agree, $36 \%$ indicated agree, $19 \%$ indicted undecided, $8 \%$ indicated disagree, while $6 \%$ of respondents indicated strongly disagree. To the third view, a mean value of $\bar{x}=3.59$ was obtained $33 \%$ of respondents indicated strongly agree, $24 \%$ indicated agree, $22 \%$ of respondents were undecided. $13 \%$ indicated disagree, while $8 \%$ indicated strongly disagree. To the fourth option, a mean value of $\bar{x}=3.63$ was obtained $24 \%$ of respondents indicated strongly agree, 36\% indicated agree, 18\% indicted undecided, 10\% indicated disagree, while $12 \%$ of respondents indicated strongly disagree. To the fifth view, a mean value of $\bar{x}=3.76$ was obtained $31 \%$ of respondents indicated strongly agree, $36 \%$ indicated agree, $19 \%$ of respondents were undecided. $8 \%$ indicated disagree, while $6 \%$ indicated strongly disagree.

Table 3: Internet Banking

\begin{tabular}{|c|c|c|c|c|c|c|c|c|}
\hline $\mathrm{S} / \mathrm{N}$ & Opinions & SA & $\mathrm{A}$ & $\mathrm{U}$ & D & SD & Mean $\bar{x}$ & Total \\
\hline & & No $\%$ & No $\%$ & No $\%$ & No $\%$ & No $\%$ & & No \\
\hline 1 & $\begin{array}{l}\text { I am willing to provide credit card } \\
\text { and purchase information over the } \\
\text { Internet when this information is } \\
\text { encrypted. }\end{array}$ & $100(31)$ & $\begin{array}{ll}56 & (17)\end{array}$ & 44 (14) & 71 (22) & $50 \quad(16)$ & 3.26 & $\begin{array}{ll}321 & 100\end{array}$ \\
\hline 2 & $\begin{array}{l}\text { Security plays a vital role in internet } \\
\text { banking adoption and continued use }\end{array}$ & $123(38)$ & $50(16)$ & $55(17)$ & 41 (13) & $52(16)$ & 3.47 & $321 \quad 100$ \\
\hline 3 & $\begin{array}{l}\text { It reduces the stress of carrying } \\
\text { money }\end{array}$ & $106(33)$ & $69(21)$ & $50 \quad(16)$ & $31(10)$ & $65 \quad(20)$ & 3.37 & $321 \quad 100$ \\
\hline 4 & $\begin{array}{l}\text { It reduces the risk of being robbed } \\
\text { by hoodlums }\end{array}$ & 88 (27) & $95(30)$ & 61 (19) & 35 (11) & 42 (13) & 3.23 & $321 \quad 100$ \\
\hline 5 & It is very fast in payment delivery & $94 \quad(29)$ & $70(22)$ & $\begin{array}{ll}60 & (19) \\
\end{array}$ & $57 \quad(18)$ & $40 \quad(13)$ & 3.27 & $321 \quad 100$ \\
\hline
\end{tabular}

Source: Survey Data, 2019

Table 3 reveals the respondents views on internet banking with a mean value of $\bar{x}=3.26$. For the first view, $31 \%$ of respondents indicated strongly agree, $17 \%$ indicated agree, $14 \%$ indicated undecided, $22 \%$ indicated disagree, while $16 \%$ of the total respondents indicated strongly disagree. To the second view, a mean value of $\bar{x}=3.47$ was obtained. $38 \%$ of respondents indicated strongly agree, $16 \%$ indicated agree, $17 \%$ indicated undecided, $13 \%$ indicated disagree, while $16 \%$ of the respondents indicated strongly disagree. To the third view, a mean value of $\bar{x}=3.37$ was obtained $33 \%$ of respondents indicated strongly agree, $21 \%$ indicated agree, $16 \%$ of respondents indicated undecided, $10 \%$ indicated disagree, while $20 \%$ of respondents strongly disagree. To the fourth view, a mean value of $\bar{x}=3.23$ was obtained. $27 \%$ of respondents indicated strongly agree, $30 \%$ indicated agree, $19 \%$ indicated undecided, $11 \%$ indicated disagree, while $13 \%$ of the respondents indicated strongly disagree. To the fifth view, a mean value of $\bar{x}=3.27$ was obtained $29 \%$ of 
British Journal of Marketing Studies (BJMS)

Vol. 8, Issue 2, pp.1-25, March 2020

Published by ECRTD- UK

Print ISSN: 2053-4043(Print), Online ISSN: 2053-4051(Online)

respondents indicated strongly agree, $22 \%$ indicated agree, $19 \%$ of respondents indicated undecided, $18 \%$ indicated disagree, while $13 \%$ of respondents strongly disagree.

Table 4: Repeat Purchase

\begin{tabular}{|c|c|c|c|c|c|c|c|c|}
\hline $\mathrm{S} / \mathrm{N}$ & Opinions & SA & A & $\mathrm{U}$ & D & SD & Mean $\bar{x}$ & Total \\
\hline & & No $\%$ & No $\%$ & No & No $\%$ & No $\%$ & & No \\
\hline 1 & $\begin{array}{l}\text { I love to continue patronizing my } \\
\text { bank due to efficient service in the } \\
\text { use of mobile banking }\end{array}$ & $100(31)$ & 56 (17) & $44 \quad(14)$ & 71 (22) & $50 \quad(16)$ & 3.26 & $321 \quad 100$ \\
\hline 2 & $\begin{array}{l}\text { Adequate support service in } \\
\text { internet banking is the reason why } \\
\text { I am loyal to my bank }\end{array}$ & $123(38)$ & $50 \quad(16)$ & $55 \quad(17)$ & 41 (13) & 52 (16) & 3.47 & $321 \quad 100$ \\
\hline 3 & $\begin{array}{l}\text { I enjoy self support service with } \\
\text { my bank ATM each time I transact } \\
\text { with them }\end{array}$ & $106(33)$ & $69(21)$ & $50 \quad(16)$ & $31(10)$ & $65 \quad(20)$ & 3.37 & $321 \quad 100$ \\
\hline 4 & $\begin{array}{l}\text { The waiting line at my bank ATM } \\
\text { is one of the reason why repeat my } \\
\text { patronage }\end{array}$ & $\begin{array}{ll}99 & (31)\end{array}$ & 71 (22) & $\begin{array}{ll}50 & \text { (16) }\end{array}$ & $\begin{array}{ll}55 \quad(17) \\
\end{array}$ & $46 \quad(14)$ & 3.45 & $\begin{array}{ll}321 \quad 100 \\
\end{array}$ \\
\hline
\end{tabular}

Source: Survey Data, 2019

Table 4 presents respondents' views on repeat purchase with a mean value of $\bar{x}=3.26$. To the first opinion, $31 \%$ of the respondents indicated strongly agree, $17 \%$ indicated agree, $14 \%$ were undecided, $22 \%$ indicated disagree while $16 \%$ indicated strongly disagree.To the second view, a mean value of $\bar{x}=3.47$ was obtained. $38 \%$ of the respondents indicated strongly agree, $16 \%$ indicated agree, $17 \%$ indicated undecided, $13 \%$ indicated disagree, while $16 \%$ of respondents indicated strongly disagree. To the third opinion, a mean value of $\bar{x}=3.37$ was obtained $33 \%$ of respondents indicated strongly agree $21 \%$ indicated agree, $16 \%$ indicated undecided, $10 \%$ indicated disagree, while $20 \%$ indicated strongly disagree. To the fourth opinion, a mean value of $\bar{x}=3.45$ was obtained $31 \%$ of respondents indicated strongly agree $22 \%$ indicated agree, $16 \%$ indicated undecided, $17 \%$ indicated disagree, while $14 \%$ indicated strongly disagree. 
British Journal of Marketing Studies (BJMS)

Vol. 8, Issue 2, pp.1-25, March 2020

Published by ECRTD- UK

Print ISSN: 2053-4043(Print), Online ISSN: 2053-4051(Online)

\section{Table 5: Referral}

\begin{tabular}{|c|c|c|c|c|c|c|c|c|}
\hline $\mathrm{S} / \mathrm{N}$ & Opinions & SA & A & $\mathrm{U}$ & $\mathrm{D}$ & SD & Mean $\bar{x}$ & Total \\
\hline & & No $\%$ & No $\%$ & No $\%$ & No $\%$ & No $\%$ & & No \\
\hline 1 & $\begin{array}{l}\text { Most of our new customers are } \\
\text { gotten from our existing customers }\end{array}$ & $110(34)$ & $50 \quad(16)$ & 59 (18) & $43 \quad(13)$ & 59 (18) & 3.34 & 321100 \\
\hline 2 & $\begin{array}{l}\text { Our competitors refer customers to } \\
\text { us due to quality services that we } \\
\text { render }\end{array}$ & $\begin{array}{ll}98 \quad(31)\end{array}$ & $\begin{array}{ll}99 & (31)\end{array}$ & $\begin{array}{ll}60 \quad(19)\end{array}$ & $45 \quad(14)$ & 39 (12) & 3.72 & 321100 \\
\hline 3 & $\begin{array}{l}\text { We make close contact with our } \\
\text { newly referred customers }\end{array}$ & $67 \quad(21)$ & $97 \quad(30)$ & 62 (19) & $29 \quad(9)$ & $66 \quad(21)$ & 3.22 & 321100 \\
\hline 4 & $\begin{array}{l}\text { Our mobile banking is so easy that } \\
\text { our customers can also teach new } \\
\text { customers to use }\end{array}$ & $105(33)$ & $78 \quad(24)$ & $\begin{array}{ll}69 & (22)\end{array}$ & $42 \quad(13)$ & $27 \quad(8)$ & 3.59 & $321 \quad 100$ \\
\hline
\end{tabular}

Source: Survey Data, 2019

Table 5 represents respondents' opinion on referral with a mean value of $\bar{x}=3.34$. To the first opinion in the table, $34 \%$ of respondents indicated strongly agree, $16 \%$ indicated agree, $18 \%$ indicated undecided, $13 \%$ indicated disagree, while $18 \%$ of the respondents strongly disagree.To the second opinion, a mean value of $\bar{x}=3.72$ was obtained $31 \%$ indicated strongly disagree, $31 \%$ indicated agree, $19 \%$ indicated undecided, $14 \%$ indicated disagree, while $12 \%$ of respondents indicated strongly disagree. To the third opinion, a mean value of $\bar{x}=3.22$ was obtained $21 \%$ of respondents indicated strongly agree, 30\% indicated agree, $19 \%$ indicated undecided, $9 \%$ indicated disagree. While, $21 \%$ of the total respondents indicated strongly disagree. To the fourth opinion, a mean value of $\bar{x}=3.59$ was obtained $33 \%$ of respondents indicated strongly agree, $24 \%$ indicated agree, $22 \%$ indicated undecided, $13 \%$ indicated disagree. While, $8 \%$ of the total respondents indicated strongly disagree.

\section{Table 6: Customer Technology Adoption}

\begin{tabular}{|c|c|c|c|c|c|c|c|c|}
\hline $\mathrm{S} / \mathrm{N}$ & Opinions & SA & $\mathrm{A}$ & $\mathrm{U}$ & $\mathrm{D}$ & SD & Mean $\bar{x}$ & Total \\
\hline & & No $\%$ & No $\%$ & No $\%$ & No $\%$ & No $\%$ & & No \\
\hline $\mathrm{CTA}_{28}$ & $\begin{array}{l}\text { I prefer transacting face to face } \\
\text { with the bank rather than using } \\
\text { the ATM }\end{array}$ & $79 \quad(25)$ & $\begin{array}{ll}80 & (25)\end{array}$ & 53 (17) & 47 (15) & 62 (19) & 3.19 & $321 \quad 100$ \\
\hline $\mathrm{CTA}_{29}$ & $\begin{array}{l}\text { Online banking technology } \\
\text { enables me to pay all my bills } \\
\text { with ease }\end{array}$ & $89 \quad(28)$ & $100(31)$ & $49 \quad(15)$ & $40 \quad(13)$ & $43 \quad(13)$ & 3.47 & $321 \quad 100$ \\
\hline $\mathrm{CTA}_{30}$ & $\begin{array}{l}\text { I would rather opt for meeting } \\
\text { the bank staff for transaction } \\
\text { than facing the hassles in the } \\
\text { usage of internet banking }\end{array}$ & $67 \quad(21)$ & $97 \quad(30)$ & 62 (19) & $29 \quad(9)$ & $66 \quad(21)$ & 3.22 & 321100 \\
\hline
\end{tabular}

Source: Survey Data, 2017

Table 6 represents respondents' opinion on customer technology adoption as a moderator on customer self service technology and customer patronage with a mean value of $\bar{x}=3.19$. To the 
British Journal of Marketing Studies (BJMS)

Vol. 8, Issue 2, pp.1-25, March 2020

Published by ECRTD- UK

Print ISSN: 2053-4043(Print), Online ISSN: 2053-4051(Online)

first opinion in the table, $25 \%$ of respondents indicated strongly agree, $25 \%$ indicated agree, $17 \%$ indicated undecided, $15 \%$ indicated disagree, while $19 \%$ of the respondents strongly disagree. To the second opinion, a mean value of $\bar{x}=3.47$. $28 \%$ indicated strongly disagree, $31 \%$ indicated agree, $19 \%$ indicated undecided, $11 \%$ indicated disagree, while $13 \%$ of respondents indicated strongly disagree. To the third opinion, a mean value of $\bar{x}=3.22 .21 \%$ of respondents indicated strongly agree, $30 \%$ indicated agree, $19 \%$ indicated undecided, $9 \%$ indicated disagree while, $21 \%$ of the total respondents indicated strongly disagree.

\section{Hypotheses Testing/Inferential Statistics}

In this section, the hypotheses proposed for this study were subjected to statistical tests using the Spearman's Rank Order Correlation Co-Efficient Statistical Tool.

\section{Decision Rule}

Reject the null hypothesis $\left(\mathbf{H}_{\mathbf{0}}\right)$ if PV $<0.01$ for 2 -tailed test and conclude that significant relationship exists.

Hypothesis One (Ho1): There is no significant relationship between automated teller machine and repeat purchase in deposit money banks in Rivers State

Table 7:Spearman's correlation showing relationship between automated teller machine and repeat purchase

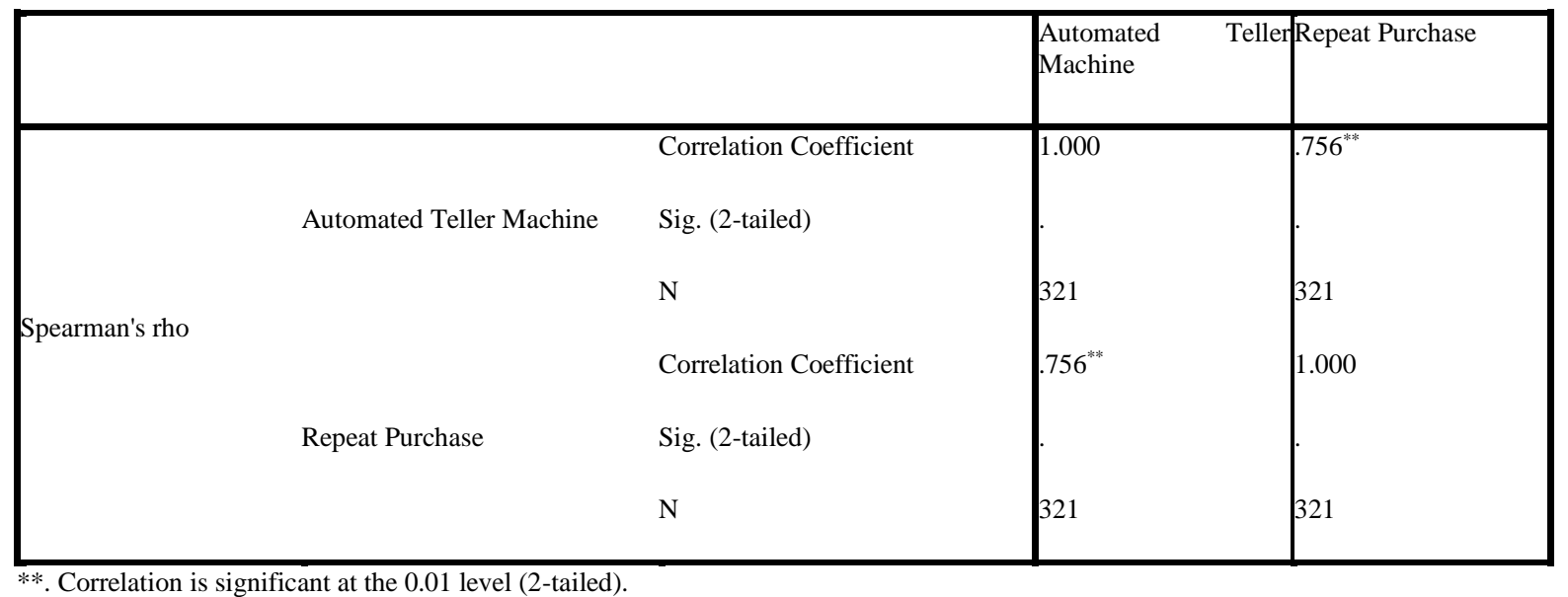

Research hypothesis one stated that, there is no significant relationship between automated teller machine and repeat purchase. The null hypothesis one was tested statistically at a 0.05 significant level and a degree of freedom of $n-2$, the correlation (r) value of $0.76(76 \%)$, revealed that there is a significant relationship between automated teller machine and repeat purchase. Therefore, the null hypothesis one was rejected and the alternative hypothesis accepted. Thus; we conclude that automated teller machine significantly influence repeat purchase. 
British Journal of Marketing Studies (BJMS)

Vol. 8, Issue 2, pp.1-25, March 2020

Published by ECRTD- UK

Print ISSN: 2053-4043(Print), Online ISSN: 2053-4051(Online)

Hypothesis Two (Ho2): There is no significant relationship between automated teller machine and referral in deposit money banks in Rivers State

Table 8: Spearman's correlation showing relationship between Automated Teller Machine and referral

\begin{tabular}{|c|c|c|c|}
\hline & & $\begin{array}{l}\text { Automated } \\
\text { Machine }\end{array}$ & Referral \\
\hline $\begin{array}{l}\text { Automated Teller Machine } \\
\text { Spearman's rho } \quad \text { S }\end{array}$ & $\begin{array}{l}\text { Correlation Coefficient } \\
\text { Sig. (2-tailed) } \\
\mathrm{N} \\
\text { Correlation Coefficient } \\
\text { Sig. (2-tailed) } \\
\mathrm{N}\end{array}$ & $\begin{array}{l}1.000 \\
321 \\
812^{* *} \\
321\end{array}$ & $\begin{array}{l}812^{* *} \\
321 \\
1.000 \\
321\end{array}$ \\
\hline
\end{tabular}

The research hypothesis two states that, there is no significant relationship between automated teller machine and referral. From the statistical testing of hypothesis two, a significant relationship was revealed to exist between automated teller machine and referral, this is shown in the positive correlation (r) value of $0.81(81 \%)$. The null hypothesis two was therefore rejected and the alternative hypothesis two accepted. Therefore, there is a significant relationship between automated teller machine and referral.

Hypothesis Three (Ho3): There is no significant relationship between Internet Banking and repeat purchase in deposit money banks in Rivers State

Table 9: Spearman's correlation showing relationship between internet banking and repeat purchase

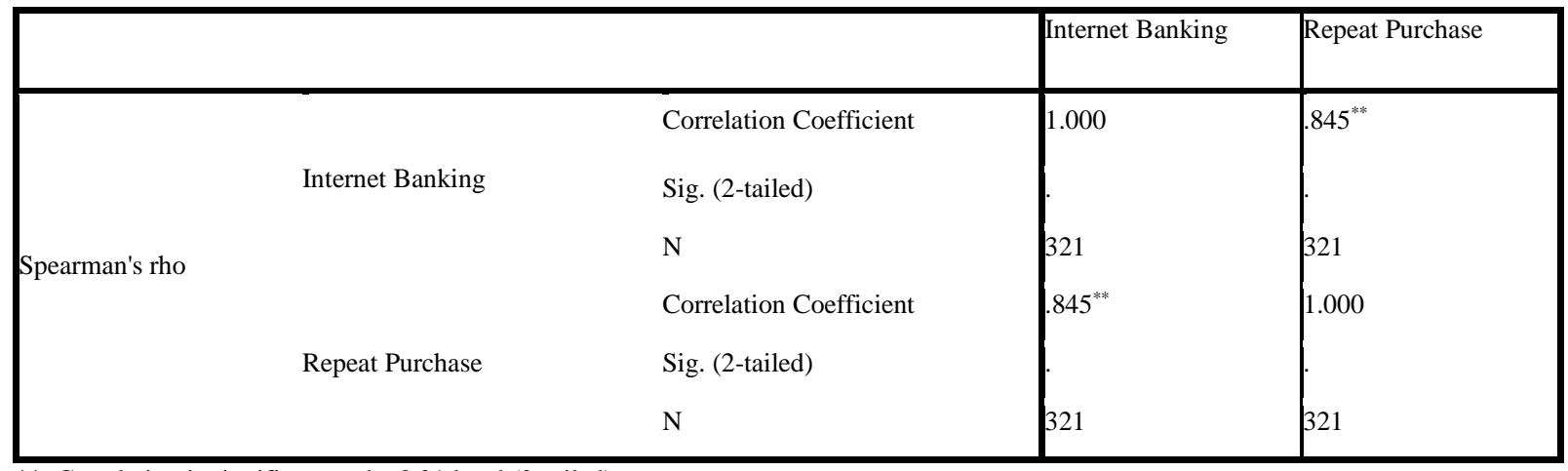

**. Correlation is significant at the 0.01 level (2-tailed). 
British Journal of Marketing Studies (BJMS)

Vol. 8, Issue 2, pp.1-25, March 2020

Published by ECRTD- UK

Print ISSN: 2053-4043(Print), Online ISSN: 2053-4051(Online)

The research hypothesis three states that, there is no significant relationship between internet banking and repeat purchase. As evident in the statistical testing of hypothesis three, a significant relationship was revealed to exist between internet banking and repeat purchase, this is evident in the positive correlation (r) value of $0.85(85 \%)$. The null hypothesis three was therefore rejected and the alternative hypothesis three accepted. Therefore, there is a significant relationship between internet banking and repeat purchase.

Hypothesis Four (Ho4): There is no significant relationship between internet banking and referral in deposit money banks in Rivers State

Table 10:Spearman's correlation showing relationship between Internet Banking and referral

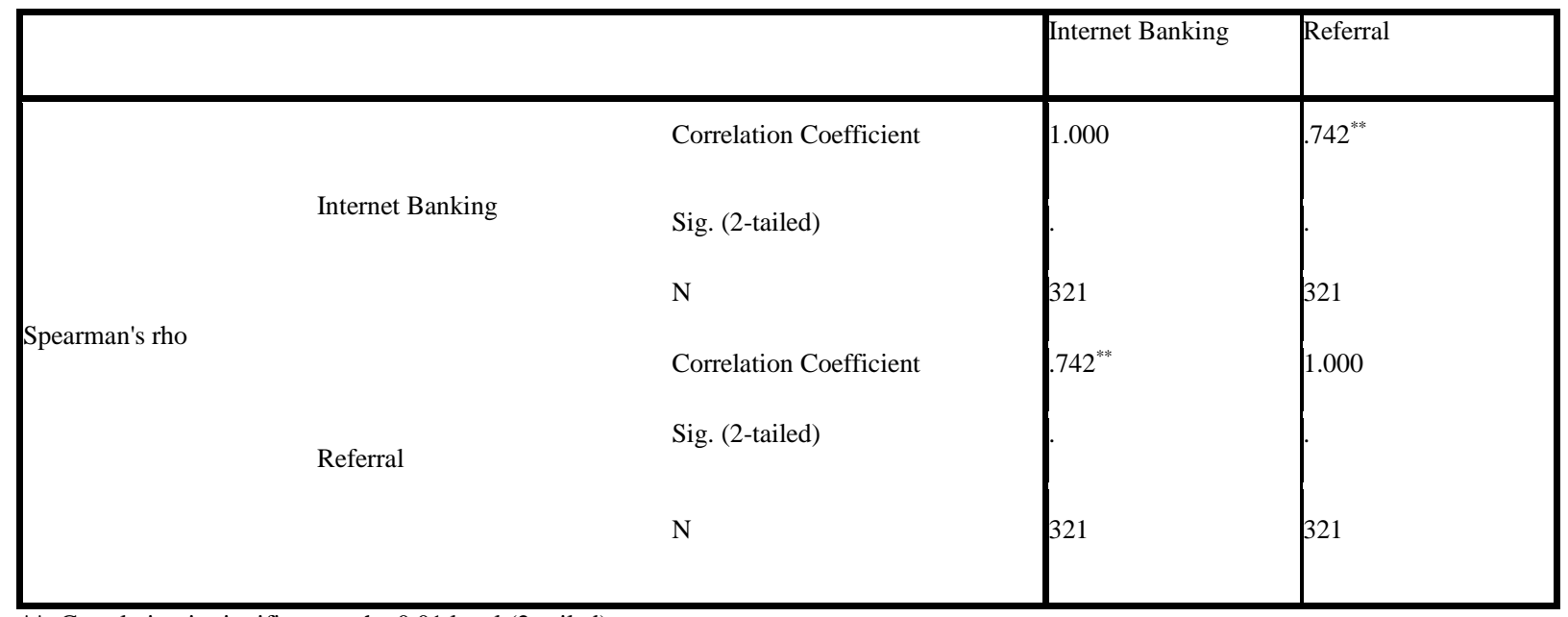

**. Correlation is significant at the 0.01 level (2-tailed).

The research hypothesis four states that, there is no significant relationship between internet banking and referral. As evident in the statistical testing of hypothesis four, a significant relationship was revealed to exist between internet banking and referral, this is evident in the positive correlation (r) value of $0.74(74 \%)$. The null hypothesis four was therefore rejected and the alternative hypothesis four accepted. Therefore, there is a significant relationship between internet banking and referral. 
British Journal of Marketing Studies (BJMS)

Vol. 8, Issue 2, pp.1-25, March 2020

Published by ECRTD- UK

Print ISSN: 2053-4043(Print), Online ISSN: 2053-4051(Online)

Hypothesis Five (Hos): Customer Technology Adoption does not significantly moderate the relationship between customer self service technology and customer patronage

Table 11: SPSS correlation result for hypothesis five

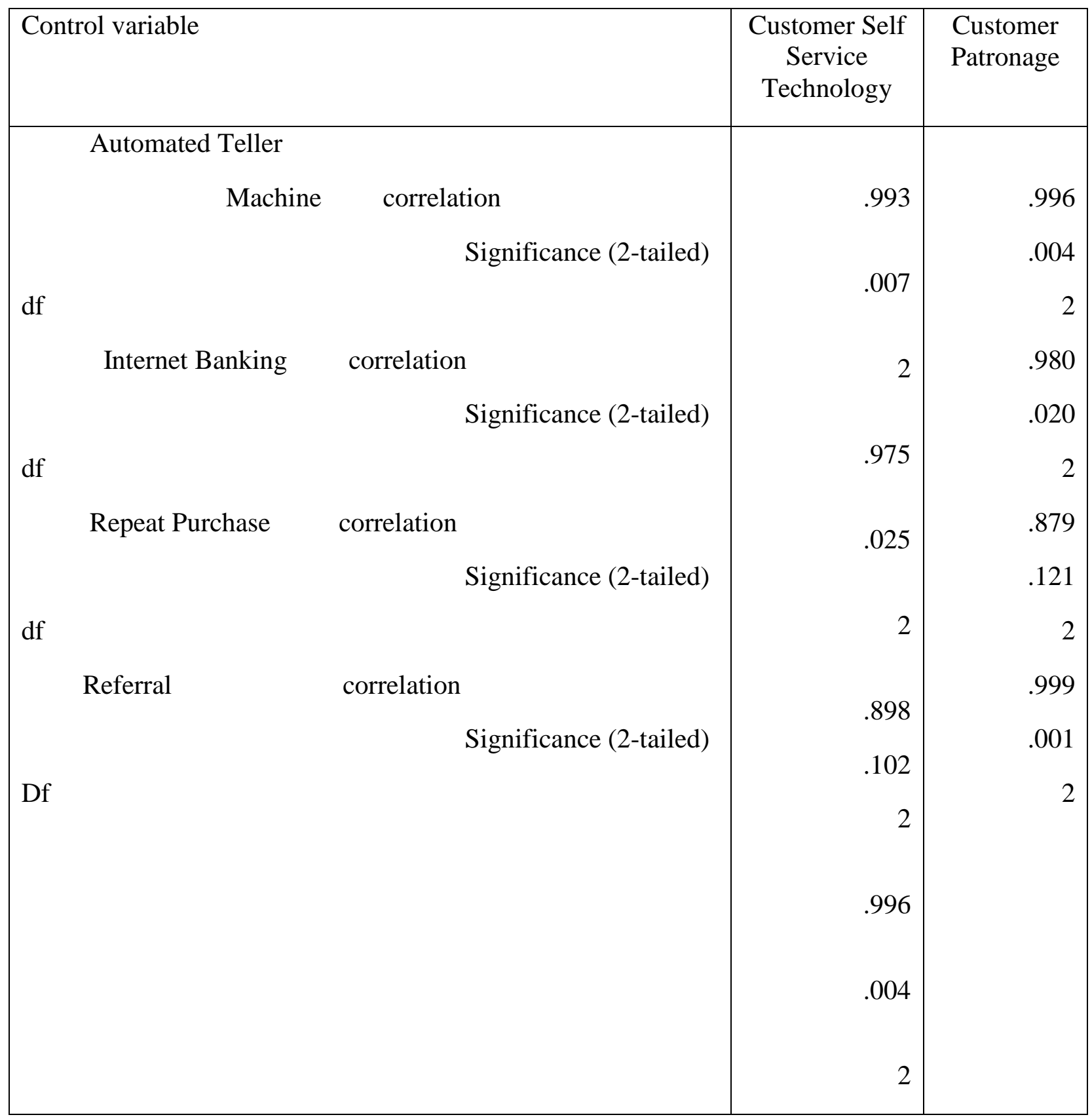

Source: SPSS Output (based on 2019 field survey data) 
From the result on partial correlation, the correlation coefficient between automated teller machine and repeat purchase (0.879), automated teller machine and referral ( $\mathrm{r}=0.996)$, with significant value (2-tailed) of 0.001. Customer technology adoption as the moderating variable was significant with all the variables. Based on that, the null hypothesis was rejected.

\section{DISCUSSIONS}

\section{Relationship between Automated Teller Machine and Customer Patronage}

From the result of the analysis, the correlation coefficient $(r=0.756)$ and $(r=0.812)$, was tested at a 0.01 significant level and a degree of freedom of $n-2$, meaning that there is a positive correlation between automated teller machine and repeat purchase, automated teller machine and referral. Inactivity of the online facility of the bank can play a significant role in customer's patronage. Some researchers, on the other hand mentioned that adequate numbers of ATMs, convenient and secure location, and user-friendly system, speed, minimum errors, high uptime, cash backup, cost and service coverage are essential service quality aspects of ATM service. The increased deployment of ATMs in the banking sector has made the issue of technology relevance important. At present, the use of ATM has been widely promoted. Some banks have resorted to penalizing the customer as it were, for not possessing an ATM card, by debiting the account of such a customer for withdrawing below a certain amount across the counter.

\section{Relationship between Internet Banking and Customer Patronage}

From the result of the analysis, the correlation coefficient $(r=0.845)$ and $(r=0.742)$ was tested at a 0.01 significant level and a degree of freedom of $n-2$, meaning that there is a positive correlation between internet banking and repeat purchase; internet banking, and referral. In response to the findings. Customers can inquire information and carry out most banking services such as account balance inquiry, inter-account transfers, and bill-payment via the Internet. There are different perceptions of Internet Banking between the literature and practitioners. It is also reported that Internet banking is a web application based on client/server architecture in which Internet technology plays an important role.

\section{IMPLICATION TO RESEARCH PRACTICE}

This study made a significant contribution to knowledge in relation to customer self service technology by introducing a moderating variable in our conceptual model to detect the mediating role between the independent and dependent variable. Furthermore, it also provided an insight into the customers' needs and wants which may be essential for bankers in order to provide better services to customers. Banks need more publicity about the security level and rules and regulation related to security. They can do so by education and publicity through the mass media. 
British Journal of Marketing Studies (BJMS)

Vol. 8, Issue 2, pp.1-25, March 2020

Published by ECRTD- $U K$

Print ISSN: 2053-4043(Print), Online ISSN: 2053-4051(Online)

\section{CONCLUSION AND RECOMMENDATIONS}

\section{Conclusion}

Based on the finding as revealed by the study, the following conclusions are made:

i.) A significant and positive relationship exists between automated teller machine and repeat purchase in deposit money banks in Rivers State

ii.) Automated teller machine influences referral in deposit money banks in Rivers State

iii.) There is a significant relationship between internet banking and repeat purchase in deposit money banks in Rivers State.

iv.) There is a significant relationship between internet banking and referral in deposit money banks in Rivers State.

v.) Customer Technology adoption positively influences the relationship between customer self service technology and customer patronage in deposit money banks in Rivers State.

\section{Recommendations}

The following recommendations are In accordance with the conclusions above, the researcher therefore recommends that:

i. Banks should invest more on technologies that will ensure efficiency in serving customer and overall satisfactions of the customers. Customer satisfaction should be kept in mind as banks upgrade existing systems or while buying new systems altogether.

ii. In order to invest in infrastructure and modern technologically mediated systems to boost their efficiencies, banks should have adequate budgets for the development of infrastructure to ensure their presence by extending their ATM networks, mobile banking and internet banking.

iii. In order to differentiate themselves, banks will need to go out of their way to deliberately listen to the needs of customers and ensure that strategies are customer focused. It is only when the banks know what the customer wants that it can be able to hear their voice and adopt voice-of-the-customer model where the customers' input especially during new product development is key.

\section{REFERENCES}

Agboola, A. (2006). Information and communication technology in banking operations in Nigeria: An evaluation of recent experiences. Retrieved November 25, 2012, from http://unpan1.Un.org/intradoc/g groups /public/documents/AAPA M/UNPAN026533.pdf.

Al-Somali, S. A, Gholami, R., \& Clegg, B. (2008). Internet banking acceptance in the context of developing countries: An extension of the technology acceptance model. 
British Journal of Marketing Studies (BJMS)

Vol. 8, Issue 2, pp.1-25, March 2020

Published by ECRTD- UK

Print ISSN: 2053-4043(Print), Online ISSN: 2053-4051(Online)

Anderson, E. W., Fornell, C., \& Lehmann, D. R. (1994). Customer satisfaction, market share and profitability: Findings from Sweden. Journal of Marketing, 58(6), 53-66.

Bitner, M.J., Ostrom, A.L., \& Meuter, M.L. (2002). Implementing successful self-service technologies. Academy of Management Executive, (16)4, 96-109. http://dx.doi.org/ 10.5465/AME.2002.8951333

Bobbitt, L., \& Dabholkar, P. (2001). Integrating attitudinal theories to understand and predict use to technology-based self-service. The internet as an illustration. International Journal of Service Industry Management, 12(5), 423-50.

Brockner, J., Higgins, E.T., \& Low, M.B. (2004). Regulatory focus theory and the entrepreneurial process. Journal of Business Venturing, 19(2), 203-220.

Brown, S. W. (2000). Pt. 4 In R. P. Fisk, S. J. Grove \& J. John (Eds.), Service marketing selfportraits: Introspections, reflections, and glimpses from the experts (53-69). Chicago, IL: American Marketing Association.

Buell, R. W., Campbell, D., \& Frei, F.X. (2010). Are self-service customers satisfied or stuck. Production and Operations Management Journal, 19(6), 679-697.

Cumby, J. A., \& Barnes, J. G. (1996). Relationship segmentation: The enhancement of databases to support relationship marketing. Paper presented at the contemporary knowledge of relationship marketing, proceedings of the third research conference on relationship marketing, Atlanta.

Cunningham, L.F., Young, C.E., Gerlach, J.H. (2008). Consumer views of self-service technologies, The Self Service Industries Journal, 28(6): 719-732, http://doi.org/10.1080/02642060801988522

Curran, J.M., Meuter, M.L., \& Surprenant, C.F. (2003). Intentions to use self-service technologies: A confluence of multiple attitudes. Journal of Service Research, 5(3), 209-241.

Davies, F. (1989). Perceived usefulness, perceived ease of use and user acceptance of information technology. MIS Quarterly, 13(3), 318-339.

Devlin, J. (1995). Technology and innovation in retail banking distribution. International Journal of Bank Marketing, 13(4), 19-25.

Dodds, W.B., Monroe, K.B., \& Grewal, D. (1991). Effects of price, brand and store information on buyers product evaluations. Journal of Marketing Research, 24(28), 307-319.

Eriksson, K., Kerem, K., \& Nilsson, D. (2005). Customer acceptance of Internet banking in Estonia. International Journal of Bank Marketing, 23(2), 200-216.

Fishbein, M., \& Ajzen, I. (1975). Belief, attitude, intention, and behavior. Reading, M.A: Addition-Wesley.

Fornell, C. (1992). A national customer satisfaction barometer: The Swedish experience. Journal of Marketing, 56, 6-21.

Friedman, R. S., \& Forster, J. (2001). The effects of promotion and prevention cues on creativity. Journal of Personality and Social Psychology, 81(6), 1001-1013.

Ganesh, J., Arnold, M.J., \& Reynolds, K.E. (2000). Understanding the customer base of service providers: An examination of the differences between switchers and stayers. Journal of Marketing, 64(3), 65-87.

Ganguli, S., \& Roy, S.K. (2011). Generic technology-based service quality dimensions in banking Impact on customer satisfaction and loyalty. International Journal of Bank Marketing, 29(2), 168-189. 
British Journal of Marketing Studies (BJMS)

Vol. 8, Issue 2, pp.1-25, March 2020

Published by ECRTD- UK

Print ISSN: 2053-4043(Print), Online ISSN: 2053-4051(Online)

Howard, M., \& Worboys, C. (2003). Self-service-a contradiction in terms or customer-led choice? Journal of Consumer Behavior, 2(4) 382-92.

Islam, R., Kumar, S., \& Biswas, P. K. (2007). Customer satisfaction of ATM service: A case study of HSBC ATM. Assessed on 13/07/09, from http://papers.ssrn.

Johns, N., \& Tyas, P. (1996). Investigating of the perceived components of the meal experience, using perceptual gap methodology. Progress in Tourism and Hospitality Research, 2(1), 15-26. International Journal of Contemporary Hospitality Management, 11(5), 205-222.

Jones, M.A., Reynolds, K.E., Mothers Baugh, D.L., \& Beatty, S.E. (2007). The positive and negative effects of switching costs on relational outcomes. Journal of Service Research, 9(4), 335-55.

Joshua, A. J. (2009). Adoption of technology enabled banking self services antecedents and consequences.

Khan, A. M. (2010). An empirical study of ATM service quality and customer satisfaction in Pakistani bank. European Journal of Social Sciences, 13(3), 333-344.

Kivela, J., Inbakaran, R., \& Reece, J. (1999). Consumer research in the restaurant environment, Part 1: A conceptual model of dining satisfaction and return patronage.

Kurniasih, A. (2012). Penabung BCA Masih paling loyal. Infobank, 394(33), 24-28.

Lassar, W.M., Manolis, C., \& Lassar, S.S. (2005). The relationship between consumer innovativeness, personnel characteristics, and online banking adoption. International Journal of Bank Marketing, 23(2), 176-199.

Lee, A. Y., Aaker, J. L. Gardner, I. (2004). Bringing the frame into focus: The influence of regulatory fit on processing fluency and persuasion. Journal of Personality and Social Psychology, 86, 205-218.

Lockwood, P., Jordan, C. H., \& Kunda, Z. (2002). Motivation by positive or negative role models: Regulatory focus determines who will best inspire us. Journal of Personality and Social Psychology, 83(4), 854-864.

Malek, A., \& Nik, K. Nik Mat (2011). Modelling the antecedents of Internet banking service adoption (IBSA) in Jordan: A structural equation modeling (SEM) approach. Journal of Internet Banking and Commerce, 16(1), 1-13.

Meuter, M.L., Ostrom, A.L., Roundtree, R.I., \& Bitner, M.J. (2000). Self-service technologies: Understanding customer satisfaction with technology-based service encounters, Journal of Marketing, 64(3), 50-64. http://dx.doi.org/10.1509/jmkg.64.3.50.18024

Olatokun, W.M., \& Igbinedion, L.J. (2009). The adoption of automated teller machines in Nigeria: An application of the theory of diffusion of innovation. Issues in Informing Science and Information Technology, 6, 373-303.

Oliver, R. (1996). Satisfaction a behavior perspective on the customer. McGraw Hill. New York.

Ombati, T.O., Magutu, P.O., Nyamwange, S.O., \& Nyaoga, R.B. (2010). Technology and service quality in the banking industry. African Journal of Business \& Management, 1, 1-16.

Parasuraman, A. (2000). Technology readiness index (TRI): A multiple-item scale to measure readiness to embrace new technologies. Journal of Service Research, 2(4), 307-20.

Proenca, J.F., \& Rodrigues, M.A. (2011). A comparison of users and non-users of banking selfservice technology in Portugal. Managing Service Quality, 21(2), 192-210.

Rogers, E.M., \& Shoemaker, F.F. (1971). Communication of innovations. The Free Press, New York. 
Vol. 8, Issue 2, pp.1-25, March 2020

Published by ECRTD- UK

Print ISSN: 2053-4043(Print), Online ISSN: 2053-4051(Online)

Rose, P. S. (1999). Commercial bank management, (4th Ed.), Irwin/McGraw-Hill: Boston, USA.

Shih, Y., \& Fang, K. (2003). The use of the decomposed theory of planned behavior to study Internet banking in Taiwan. Internet Research Electronic Network Application Policy, 14(3), 213-223.

Sulek, J. M., \& Hensley, R. L. (2004). The relative importance of food, atmosphere and fairness of wait. Cornell Hotel and Restaurant Administration Quarterly, 45(3), 235-247.

Sullivan, T.J. (2001). Methods of social research, Fort Worth, TX; London: Harcourt College Publishers, Vol 19, 511(68), pp $2-25$.

Wirtz, J., \& Lwin, M.O. (2009). Regulatory focus theory, trust and privacy concern. Journal of Science Research, 12(2), 190-207.

Woelfel, C.J. (1994). The dictionary of banking. Illinois, NY: Probus Publishing

Wungwanit-Chakorn, A. (2000). Adoption intention of banks' customer on internet banking service. ABAC Journal, 22 (3), 63-80.

Yavas, U., Bilgin, Z., \& Shemwell, D. (1997).Service quality in the banking sector in an emerging economy: A consumer survey. International Journal of Bank Marketing, 15(6), 217-23.

Zeithaml, V.A. (1988). Consumer perceptions, quality and value: A means-end model and synthesis of evidence. Journal of Marketing, 52, 2-22.

Zeithaml, V. A., Parasuraman, A., \& Berry, L. L. (1990). Delivering quality service: Balancing customer perceptions and expectations. New York, NY: Free Press. 